\title{
PENGEMBANGAN MODEL MANAJEMEN ICT CENTER
}

\author{
Hakkun Elmunsyah \\ Universitas Negeri Malang \\ hakkun@um.ac.id
}

\begin{abstract}
Abstrak: Pengembangan Model Manajemen ICT Center. Kemendiknas telah melakukan investasi cukup besar berupa pembangunan Jejaring komputer pendidikan nasional yang disebut Jaringan Pendidikan Nasional (Jardiknas), pada sekolah menengah kejuruan (SMK) di seluruh Indonesia yang dikenal dengan nama ICT center. Penelitian ini bertujuan untuk menemukan model manajemen ICT center sesuai karakteristik SMK sehingga dapat memberikan kontribusi mutu pada SMK tersebut. Penelitian ini merupakan penelitian pengembangan atau Research and Development yang dikembangkan oleh Borg and Gall. Hasil secara keseluruhan penelitian menunjukkan berdasarkan uji coba keefektivan kinerja manajemen pada skala terbatas dan lebih luas menunjukkan bahwa model manajemen ICT center memenuhi kriteria sangat efektif.
\end{abstract}

Kata-kata kunci: Jardiknas, SMK, model manajemen ICT center, kontribusi mutu

\section{DEVELOPING A MODEL OF ICT CENTER MANAGEMENT}

\begin{abstract}
Developing a Model of ICT Center Management. The Ministry of National Education has made considerable investments in building National Education Computer Networks in vocational high schools (VHSs) all over Indonesia, well-known as ICT Centers. This study aims to develop a model of ICT Center management in accordance with the characteristics of VHSs so that it can give contributions to the quality of VHSs. This study was a research and development study using a model by Borg and Gall. The results for all of the study is small-scale and large-scale tryouts on the effectiveness of the management performance show that the model of the ICT center management is very effective.
\end{abstract}

Keywords: National Education Computer Networks, VHSs, model of ICT center management, contribution to quality

\section{PENDAHULUAN}

Perkembangan iptek micro electronics hingga saat ini membawa dampak revolusi digital yaitu pertumbuhan pesat ICT (Information and Communication Technology) yang mengubah seluruh aspek kehidupan manusia, seperti cara orang-orang berpikir, berperilaku, berkomunikasi, bekerja, dan menghidupi diri. Revolusi digital ini menyediakan cara baru menciptakan pengetahuan dan teknologi yang menghasilkan produk-produk elektronik dan mendidik orangorang, serta menyebarkan informasi. Revolusi ini menstruktur ulang bagaimana belajar dan mengajar, bagaimana praktek ekonomi dan bisnis dijalankan, bagaimana pemerintahan dijalankan, komunikasi dijalankan, serta politik dilibatkan. Revolusi ini juga membuka peluang meningkatkan standar hidup bagi jutaan orang di dunia, termasuk menjebatani kesenjangan di dunia pendidikan pada tempat dan waktu yang berbeda. 
Berdasarkan perkembangan teknologi dan pemanfaatannya, pendidikan di Indonesia nampak telah diantisipasi oleh Depdiknas melalui Renstra Kementrian 2010-2014 yang mengacu pada visi Rencana Pembangunan Jangka Menengah Nasional (RPJMN) 20102014 yaitu Indonesia yang sejahtera, demokratis dan berkeadilan serta arahan Presiden untuk memperhatikan aspek change and continuity, de-bottlenecking dan enhancement program pendidikan, selain itu juga mengacu Rencana Pembangunan Pendidikan Nasional Jangka Panjang 2005-2025. Pada Rencana Strategis Departemen Pendidikan Nasional 2005-2009 telah merumuskan Tiga Pilar Kebijakan Umum Pembangunan Pendidikan Nasional yaitu: (1) peningkatan pemerataan dan perluasan akses pendidikan; (2) peningkatan mutu, relevansi, dan daya saing pendidikan; serta (3) penguatan tata kelola, akuntabilitas, dan citra publik pengelolaan pendidikan. Ketiga rumusan diatas tersebut merupakan penyempurnaan sistem pendidikan berdasarkan temuan dari sejumlah permasalahan dan tantangan yang cukup kompleks dari renstra sebelumnya. Permasalahan pendidikan nasional yang dimaksud adalah: (1) masih rendahnya pemerataan dan akses pendidikan, (2) masih rendahnya mutu, relevansi dan daya saing pendidikan, dan (3) masih lemahnya tata kelola, akuntabilitas, dan citra publik pengelolaan pendidikan.

Langkah strategis yang dapat dilakukan untuk mengatasi permasalahan diatas serta Indonesia sebagai negara kepulauan, adalah dengan memanfaatkan teknologi sebagai tools dalam proses pembelajaran dan tool manajemen pendidikan, maka penggunaan ICT adalah mutlak diterapkan pada dunia pendidikan. Pendidikan atau Pelatihan Jarak Jauh (PJJ) baik secara on-line maupun off-line merupakan upaya yang harus dilakukan pada bidang pendidikan.

Gatot, H.P., dkk (2008) menjelaskan bahwa Departemen Pendidikan Nasional pada tahun 2005/2006 telah melakukan investasi pembangunan Jejaring Pendidikan Nasional yang disebut Jardiknas. Hingga saat ini dipastikan sudah melebihi dari koneksi yang terjadi pada awal pembentukan Jardiknas yaitu 33 Kantor Dinas Pendidikan Provinsi, 390 Kantor Dinas Pendidikan Kabupaten/Kota, 3 unit Depdiknas Pusat, 2 PPPG, 5 BPPLSP, 1 LPMP, 272 Kota Kabupaten/Kota, dan 3.500 Sekolah (SchoolNet) telah terhubung secara intranet dengan Jardiknas. Pada tahun ini pula oleh Diknas dibentuk program Information and Communication Technology (ICT) Center yang berfungsi sebagai Pusat Pendidikan, Pelatihan dan Pengembangan Teknologi Informasi dan Komunikasi di Kabupaten/Kota.

Harapan dan realita sering kali tidaklah sinkron, pada kenyataannya hal ini secara teoritis tidaklah sama dengan implementasi yang cukup kompleks dalam pelaksanaannya. Pengorganisasian ICT secara nasional menuntut kesiapan secara teknis maupun non teknis dalam implementasi secara real dari end user sampai dengan tingkat NOC di Depdiknas. Dari tingkat ICT Center di daerah-daerah peningkatan manajemen pengelolaan hingga penataan LAN (Local Area Network) merupakan suatu hal yang 
sangat penting. Kekontrasan antara harapan dan kenyataan, terlihat pada saat pelaksanaan program PJJ S1 PGSD dan PJJ D3 TKJ, dimana support infrastruktur yang dibangun dengan triliunan rupiah tersebut tidaklah dapat signifikan dalam mendukung pelaksanaan program jarak jauh Depdiknas tersebut.

Kondisi realita ICT terkini tersebut, nampak pada studi penelitian pendahuluan yang di lakukan pada SMKN-4 Malang sebagai ICT center Kota Malang dan di SMKN-1 Singosari sebagai ICT center Kabupaten Malang. Survey dilakukan dengan metode wawancara pada pihak-pihak yang memiliki otoritas pengelolaan ICT center dan observasi peran ICT center terhadap mutu sekolah. Secara garis besar, terjadi penurunan kualitas dan fungsi dari manajemen ICT center antara lain karena adanya perubahan dari tingkat pusat dari BKLN ke PUSTEKOM dan kebijakan koneksi jaringan Jardiknas-Inherent dari PT. Telkom ke PT. Lintas Arta, serta lemahnya komitmen sekolah terhadap teknologi informasi komunikasi sekolah.

Berdasarkan kajian tersebut menunjukkan bahwa pengelolaan ICT center di bidang pendidikan perlu mendapatkan perhatian yang serius dari berbagai pihak terkait, termasuk mengatasi masalah-masalah yang sering terjadi. Berdasarkan Rencana Strategis (Renstra) Departemen Pendidikan Nasional tahun 20052009, untuk dapat memberikan pelayanan prima, salah satu yang perlu dilakukan adalah pengembangan teknologi informasi dan komunikasi (ICT) yang dilakukan melalui pendayagunaan ICT di bidang pendidikan yang mencakup peran ICT sebagai substansi pendidikan, alat bantu pembelajaran, fasilitas pendidikan, standar kompetensi, penunjang administrasi pendidikan, alat bantu manajemen satuan pendidikan, dan infrastruktur pendidikan.

Laudon, Kenneth C. and Jane P. L. (2002:372-3) mengungkapkan bahwa manajemen pengetahuan berfungsi meningkatkan kemampuan organisasi untuk belajar dari lingkungannya dan menggabungkan pengetahuan ke dalam proses bisnis. Manajemen pengetahuan adalah serangkaian proses yang dikembangkan dalam suatu organisasi untuk menciptakan, mengumpulkan, memelihara dan mendiseminasikan pengetahuan organisasi tersebut.

Menurut Nonaka dan Takeuchi (1995) perusahaan Jepang mempunyai daya saing karena mereka memahami bahwa knowledge merupakan sumber dari daya saing, knowledge ini harus dikelola (managed), karena harus direncanakan dan diimplementasikan. Untuk mencapai budaya institusi yang inovatif, maka upaya membangun knowledge sharing (berbagi knowledge) perlu dilakukan. Kunci utama pelaku knowledge sharing adalah manusia. Keuntungan dari orang yang berbagi knowledge, adalah mereka mampu merespon kesempatan secara cepat, inovatif dapat diciptakan bukan bersifat reinventing the wheel, agar mencapai sukses di bisnis secara cepat dan biaya murah.

Jika diteliti dari beberapa fungsi manajemen, setiap ahli mempunyai pandangan yang sama dalam hal perencanaan, pengorgansasian, dan pengendalian atau pengawasan. Perbedaan pokok dari fungsi 
manajemen diluar ketiga fungsi tadi adalah menyangkut bidang pelaksanaannya saja. Untuk memudahkan memetakan wewenang dan tanggungjawab dari unit organisasi maka pendekatan konsep Plan, Do, Check, Action (PDCA) dapat digunakan dalam hal ini.

Konsep manajemen Kaizen adalah suatu filosofi dari Jepang yang memfokuskan diri pada pengembangan dan penyempurnaan secara terus menerus atau berkesinambungan dalam perusahaan bisnis. Kaizen melibatkan pemodal, karyawan dan manajer semua lini dalam perusahaan untuk pengembangan perusahaan ke arah yang lebih baik.

Pendekatan manajemen Kaizen sebagaimana Gambar 1, merupakan suatu teknik yang digunakan untuk mencapai peningkatan kinerja sesuai dengan rencana secara 'continuous improvement'. Langkah melakukan pendekatan manajemen dengan semangat Kaizen pada dasarnya terdapat tiga fase utama: Pertama, fase Kaizen preparation, yakni menetapkan target dan ruang lingkup, memilih anggota tim cross functional yang tepat, mengalokasikan sumber daya untuk memastikan bahwa proses dapat diobservasi dan data lengkap, serta berkomunikasi dengan stakeholders.

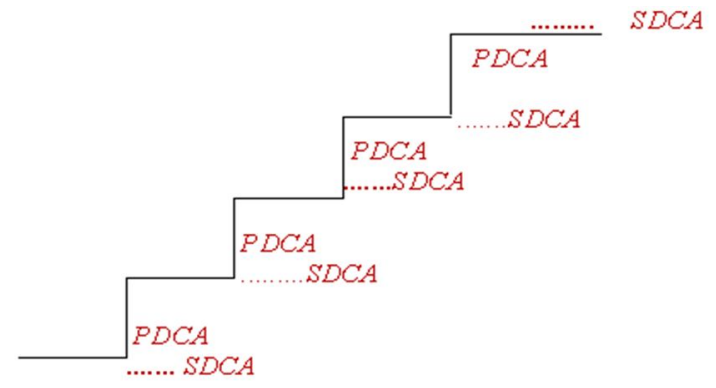

Keterangan PDCA: Plan, Do, Check, Action SDCA: Standard, Do, Check, Action.

Gambar 1. Continuos Improvement (Kaizen)
Berdasarkan teori-teori dan hasil penelitian DeLone dan McLean (1992), mengembangkan suatu model kesuksesan ICT sebagaimana Gambar 2. Model yang diusulkan tersebut merefleksikan ketergantungan dari enam pengukuran kesuksesan sistem informasi. Keenam komponen pengukuran tersebut adalah (1) kualitas sistem (system quality), (2) kualitas informasi, (information quality), (3) pengguna (user), (4) kepuasan pemakai (user satisfaction), (5) dampak individual (individual impact), (6) dampak organisasi (organization impact).

Model kesuksesan ICT dari Gambar 2, merupakan ilustrasi kualitas perangkat lunak, perangkat keras dan data merupakan kunci kontribusi mutu pada sekolah. Dalam model tersebut diungkapkan bahwa Mutu, tidaklah identik dengan hal yang mewah dan cenderung membutuhkan biaya yang mahal. Makna mutu terbebas dari opini subyektif dan terukur, definisi mutu lebih mengacu pada "memenuhi persyaratan atau kebutuhan dari pengguna". Inilah pengertian mutu yang harus dipahami oleh setiap orang. Artinya, bahasa mutu hanya satu yaitu memenuhi persyaratan atau kebutuhan pengguna yang telah ditentukan, dalam hal ini sesuai dengan aspek-aspek manajemen ICT yang telah direncanakan.

Berdasarkan perspektif model kesuksesan ICT tersebut dapat diungkapkan bahwa Quality Management System merupakan sistem manajemen yang menggunakan dasar pendekatan kepuasan pengguna (user). Sistem ini bertujuan untuk menjamin kesesuaian proses dengan produk yang dihasilkan. Kriteria kesesuaian ditunjukkan oleh kemampuan untuk 
menghasilkan produk yang sesuai dengan persyaratan atau kebutuhan penggunanya, persyaratan atau kebutuhan ditentukan oleh pengguna dan organisasi.

Hasil penelitian lain yang mendukung kegiatan ini dilakukan oleh Schreurs (2007), hasil ini mengungkapkan bahwa penerapan ICT di sekolah memerlukan adanya visi pemanfaatan ICT, formulasi tujuan strategis, perencanaan dan pengorganisasian pemanfaatan ICT di sekolah.

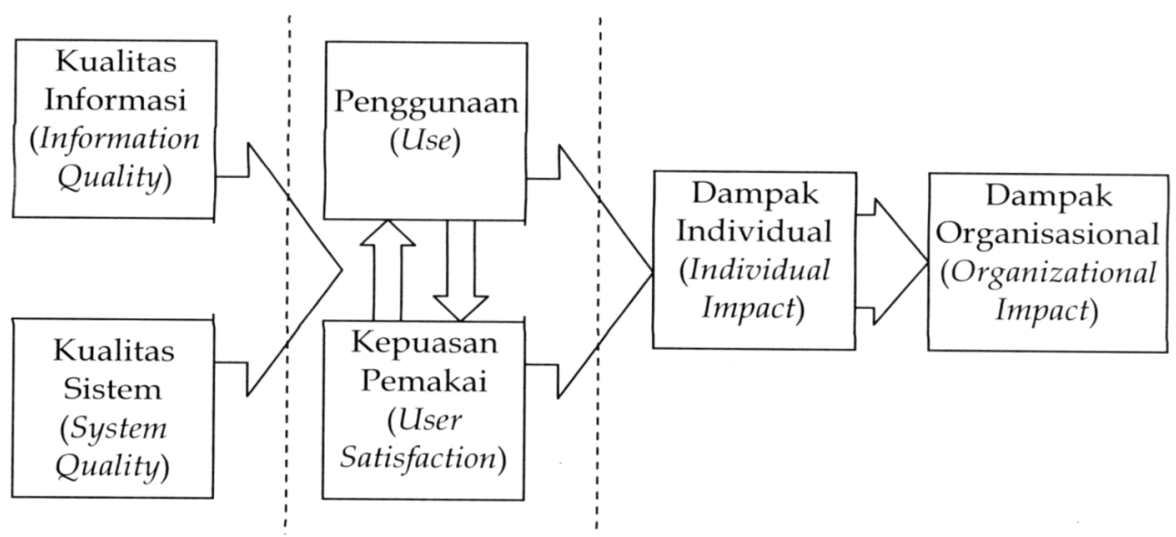

Gambar 2. Model Kesuksesan ICT (DeLone dan McLean, 1992)

Berdasarkan latar belakang masalah tersebut, dalam penelitian ini berusaha mengembangkan model pengelolaan ICT center pada SMK yang dimulai dengan observasi yang terlebih dahulu dilakukan, selanjutnya diimplementasikan model manajemen yang di kembangkan sesuai dengan karakteristik sekolah menengah kejuruan sebagai pengelola ICT center. Diharapkan melalui pengembangan manajemen ICT center ini dapat memberi kontribusi mutu sekolah yang dapat memuaskan stakeholders.

\section{METODE}

Penelitian ini merupakan penelitian pengembangan (developmental research) dengan mengacu kepada beberapa kajian teoretik tentang prosedur pengembangan yang sudah baku dan hasil identifikasi serta analisis kebutuhan. Secara konseptual dan prosedural, model pengembangan yang digunakan sebagai kajian pada penelitian dan pengembangan ini merujuk pada Educational Research and Development $(R \& D)$ yang dikembangkan oleh Borg dan Gall. Tahapan-tahapan tersebut menurut Borg \& Gall (1989: 784-785) secara rinci dijelaskan dikategorikan dalam kelompok sebagaimana berikut, yaitu: Pertama, terdiri (1) penelitian dan pengumpulan informasi (research and information collecting), (2) perencanaan (planning), (3) membangun pra-rencana produk (develop preliminary form of product); Kedua, terdiri dari (1) melakukan uji pendahuluan di lapangan (preliminary field testing), (2) melakukan revisi produk (main product revision), (3) melakukan uji produk di lapangan (main field testing), (4) merevisi produk operasional (operational product revision), (5) melakukan uji operasional di lapangan (operational field testing), (6) merevisi produk 
akhir (final product revision), selanjutnya (7) penyebaran dan pelaksanaan (dissemination and implementation).

Uji coba produk pengembangan model manajemen ICT center terdiri dari: (1) desain uji coba, yang menggunakan desain deskriptif dengan memfokuskan pada uji lapangan; (2) subyek uji coba dibagi menjadi dua kelompok yaitu melalui validasi model oleh para ahli yang berkompeten dan uji lapangan di sekolah menengah kejuruan pengelola ICT center dengan kategori pengelolaan ICT center di Kota; (3) jenis data dalam penelitian pengembangan ini bersifat statistik deskriptif berupa data kuantitatif dan kualitatif, data tersebut diperoleh dengan menggunakan 3 macam instrumen yaitu instrumen survey, instrumen validasi model dan instrumen uji coba produk, data instrumen survey diperoleh dari hasil pengisian angket dan wawancara pada para penanggung jawab ICT center di SMK tersurvei yang diperkuat dengan catatan peneliti dari hasil observasi; (4) instrumen pengumpul data berupa angket dan pedoman wawancara; dan (5) teknik analisis data dari data yang telah terhimpun dianalisis melalui tiga teknik, yaitu (a) analisis tingkat kelayakan; (b) analisis validitas dan reabilitas instrument; dan (c) analisis keefektifan model produk. Tujuan uji coba produk adalah untuk mendapatkan data yang dapat dipergunakan untuk dasar dalam melakukan revisi/perubahan terhadap produk yang didesain agar menghasilkan produk pengembangan model manajemen ICT center yang diharapkan.

Azwar (2003:152-153) menyatakan bahwa konsistensi antara skor pernyataan dengan skor skala sikap secara keseluruhan dapat pula dilihat dari besarnya koefisien korelasi antara setiap skor pernyataan dengan skor total. Koefisien korelasi inilah yang digunakan oleh Likert dalam analisis itemnya dan dikenal dengan nama "criterion of internal consistency”. Formula korelasi yang digunakan dalam hal ini adalah formula korelasi product moment dari Pearson. Penghitungan nilai korelasi ini dapat dilakukan dengan bantuan komputer program SPSS 19 for Windows.

\section{HASIL PENELITIAN DAN PEMBAHASAN}

Dalam dunia pendidikan, keberadaan ICT atau sering disebut sebagai teknologi informasi dan komunikasi merupakan salah satu komponen yang tidak dapat dipisahkan dari aktivitas pendidikan. Sebuah lembaga pendidikan harus memiliki komponenkomponen yang diperlukan untuk menjalankan operasional pendidikan, seperti siswa, sarana dan prasarana, struktur organisasi, proses, sumber daya manusia (tenaga pendidik), dan biaya operasi. Sedangkan teknologi informasi dan komunikasi terdiri dari komponenkomponen pendukung lembaga pendidikan untuk menyediakan informasi yang dibutuhkan para pemangku kepentingan, dengan demikian agar sinergi terjadi maka diperlukan pengelolaan ICT yang baik sehingga dapat memberi kontribusi mutu pendidikan secara optimal.

Oleh sebab itu, sebagai upaya untuk mengembangkan peran ICT center di sekolah manengah kejuruan, diperlukan sebuah model manajemen ICT center yang dapat memberikan kontribusi mutu pendidikan melalui kepuasan 
para pemangku kepentingan dari sekolah. Model manajemen ICT center ini dikembangkan berdasarkan proses yang cukup panjang yaitu kajian teori, penelitian pendahuluan, validasi dari para pakar, serta uji coba produk dalam skala terbatas dan luas. Selanjutnya model ini akan diusulkan dengan nama manajemen ICT center Esemka.

Penelitian ini menghasilkan produk pengembangan yang valid melalui experts judgment, efektif melalui struktur organisasi mudah dikembangkan dan memangkas birokratis, serta efektif melalui uji beda dari responden stakeholders ICT center. Produk penelitian ini diwujudkan dalam bentuk buku panduan model manajemen ICT center, perangkat modul-modul diklat manajemen ICT dan instrumen evaluasi.

Analisis dalam uji efektifitas model manajemen ICT center ini digunakan PairedSamples $T$ Test yang digunakan untuk membandingkan rara-rata dua variabel dalam satu group. Studi ini dilakukan dua pengukuran dengan subyek yang sama, satu sebelum dan satu setelah ICT center Kota serta Kabupaten Malang ini mendapat perlakuan atau suatu stimulus, waktu perlakuan masing-masing ICT center adalah empat bulan. Perlakuan tersebut berupa (1) Focus Groups Discussion (FGD) bersamaan pada kegiatan diklat, dengan peserta Kepala Sekolah, Wakasek, Guru TIK, dan manajemen ICT center. Kegiatan ini dilakukan untuk memperoleh gambaran manajemen saat ini dan rancangan manajemen kedepan. Selanjutnya secara bersama-sama menentukan visi, misi, strategi dan tujuan, serta struktur organisasi manajemen ICT center; (2) pemberian workshop untuk penguatan manajemen ICT center; (3) sosialisasi program ICT center pada internal stakeholders sekolah dan pendampingan ICT center.

Pelaksanaan uji coba produk pada tahap ini, pengelolaan datanya menggunakan program IBM SPSS release 19 dan perekaman statistik web portal sekolah selama 4 bulan yang diambil dari perangkat server ICT center, adapun hasil output yang ada pada lampiran terdiri dari: (1) Statistik deskriptif untuk masing-masing variabel yang diuji, (2) Pearson korelasi antara masing-masing variable pasangan, dan (3) suatu interval kepercayaan untuk rata-rata perbedaan. Analisis yang pada bagian ini menjelaskan uji efektifitas berdasarkan perspektif manajemen ICT center, korelasi masing-masing variable dan komparasi kinerja manajemen ICT center melalui web statistic dari aktivitas stakeholders sekolah.

Pada pengujian efektifitas kinerja manajemen ICT center secara keseluruhan menggunakan perbandingan purata (mean) dari samples stakeholders sekolah pada kondisi sebelum manajemen ICT centernya mendapat perlakuan. Adapun hipotesisnya adalah sebagai berikut:

Ho: $\mu_{\text {pretest }} \leq \mu_{\text {posttest }}$ dan $\mathrm{H}_{1}: \mu_{\text {pretest }}>\mu_{\text {posttest }}$

Dalam pengujian hipotesis, kriteria untuk menolak atau tidak menolak Ho berdasarkan Significant (Sig. dalam SPSS) sebagaimana berikut ini,

Jika Sig. $<\alpha$ maka Ho ditolak, sedang Jika Sig. $\geq \alpha$ maka Ho tidak dapat ditolak atau diterima. 
Penelitian ini menghasilkan produk pengembangan yang valid melalui experts judgment, efektif melalui struktur organisasi mudah dikembangkan dan memangkas birokratis, serta efektif melalui uji beda dari responden stakeholders ICT center. Produk penelitian ini diwujudkan dalam bentuk buku panduan model manajemen ICT center, perangkat modul-modul diklat manajemen ICT dan instrumen evaluasi.

Model manajemen ICT center berawal dari studi penelitian kondisi ICT center dengan sampling di 12 Kota atau Kabupaten di wilayah Jawa Timur. Model manajemen ICT center ini bertujuan memberi kontribusi mutu bagi sekolahnya melalui perspektif sumberdaya yang dimiliki, proses internal serta keluaran organisasi ICT center. Adapun aspek yang amati dari ICT center ini adalah SDM, teknologi, organisasi, inovasi, proses operasi, pemasaran, purna jual, produk dan layanan.

Kajian produk ini digunakan instrumen kepuasan stakeholders SMKN-4 Malang dan SMKN-1 Singosari sebagai ICT center Kota dan Kabupaten Malang. Selain itu digunakan juga statistik web portal kedua sekolah tersebut sebagai perbandingan grafik times series aktivitas stakelholders selama uji coba produk penelitian. Kajian produk ini, menampilkan grafik dari kepuasan stakeholders dari sembilan aspek kinerja manajemen ICT center di tingkat Kota dan Kabupaten Malang dari sebelum dan sesudah ada perlakuan berupa diklat, sosialisasi serta pendampingan. Pada masing-masing grafik efektifitas manajemen tersebut juga di perbandingkan dengan rata-rata dari hasil survey sebelumnya.

Hasil ujicoba ini terbukti dapat berhasil dilakukan peningkatan kepuasan stakeholders ICT center, hal tersebut nampak dari Gambar 3 dan 4. terlihat suatu perbedaan antara hasil survey, pretest dan posttest. Komparasi ketiga hasil pada Gambar 3 dan 4 tersebut mempunyai karakteristik yang responden berbeda dengan aspek yang sama. Penilaian responden dari survey adalah persepsi dari manajemen ICT center terhadap aspek-aspek manajemen pada kondisi terkini, hal ini merupakan kunci dari keberhasilan pengelolaan suatu organisasi utamanya ICT center.

Revisi produk sebagaimana yang dijelaskan pada subbab sebelumnya, telah mengalami beberapa perubahan pada membangun pra-rencana produk melalui promotor, selanjutnya pada uji pendahuluan melalui experts judgment. Pada Uji coba skala terbatas dan luas tidak ada perubahan pada model, namun terjadi perubahan pada modul manajemen ICT sebagai produk penelitian dan implementasi manajemen ICT center melalui perubahan dari visi, misi, tujuan dan strategi yang menyesuaikan situasi dan kondisi SMK, sebagai unit induk dari ICT center Kota dan Kabupaten Malang. 


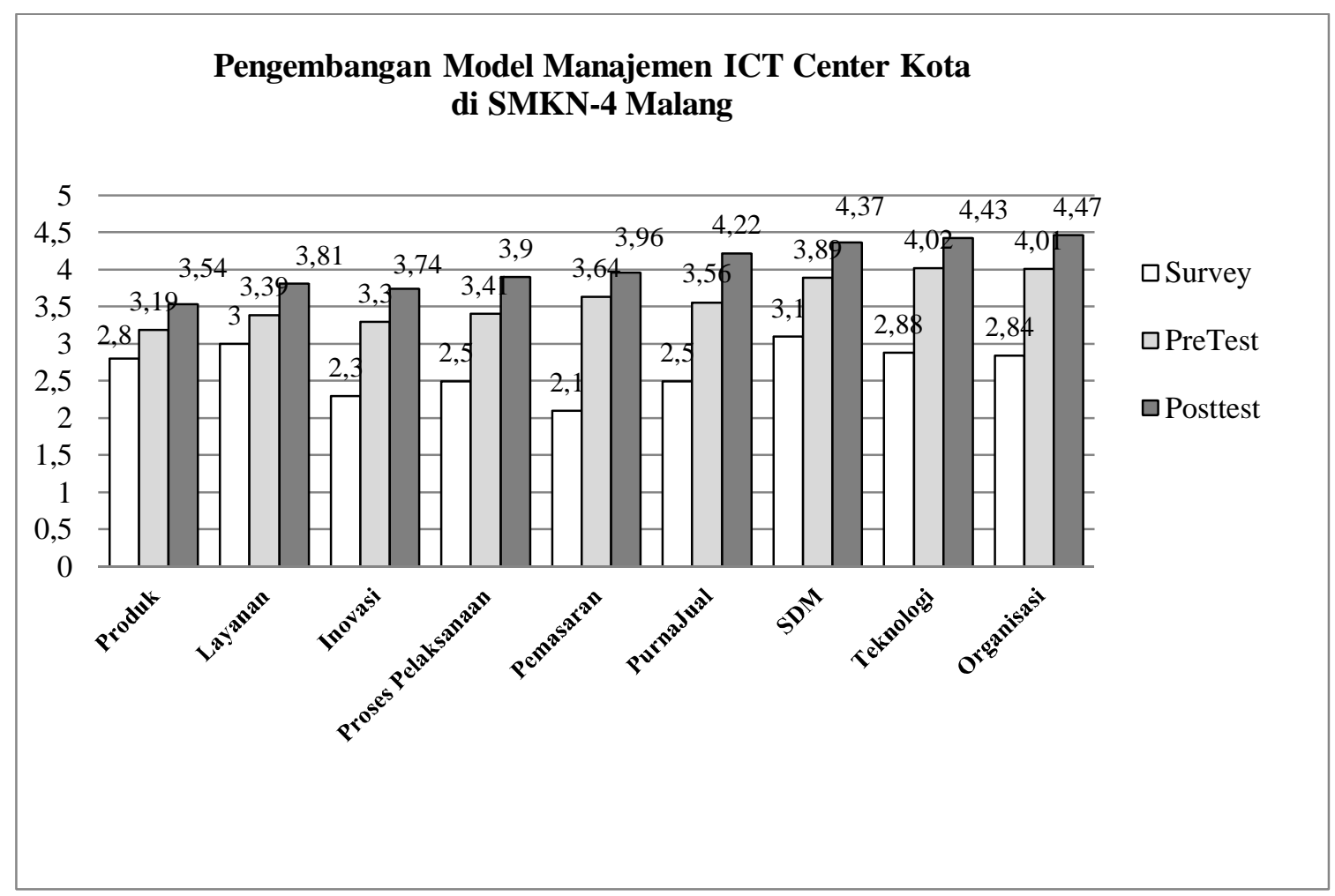

Gambar 3. Rerata penilaian aspek manajemen pada survey, pretest dan posttest

Secara keseluruhan pengembangan model manajemen ICT center ini dalam implementasinya dapat dikatakan cukup memuaskan, setelah di uji cobakan pada ICT center Kota di SMKN-4 Malang serta penerapan untuk skala yang lebih luas di ICT center Kabupaten Malang pada SMKN-1 Singosari.

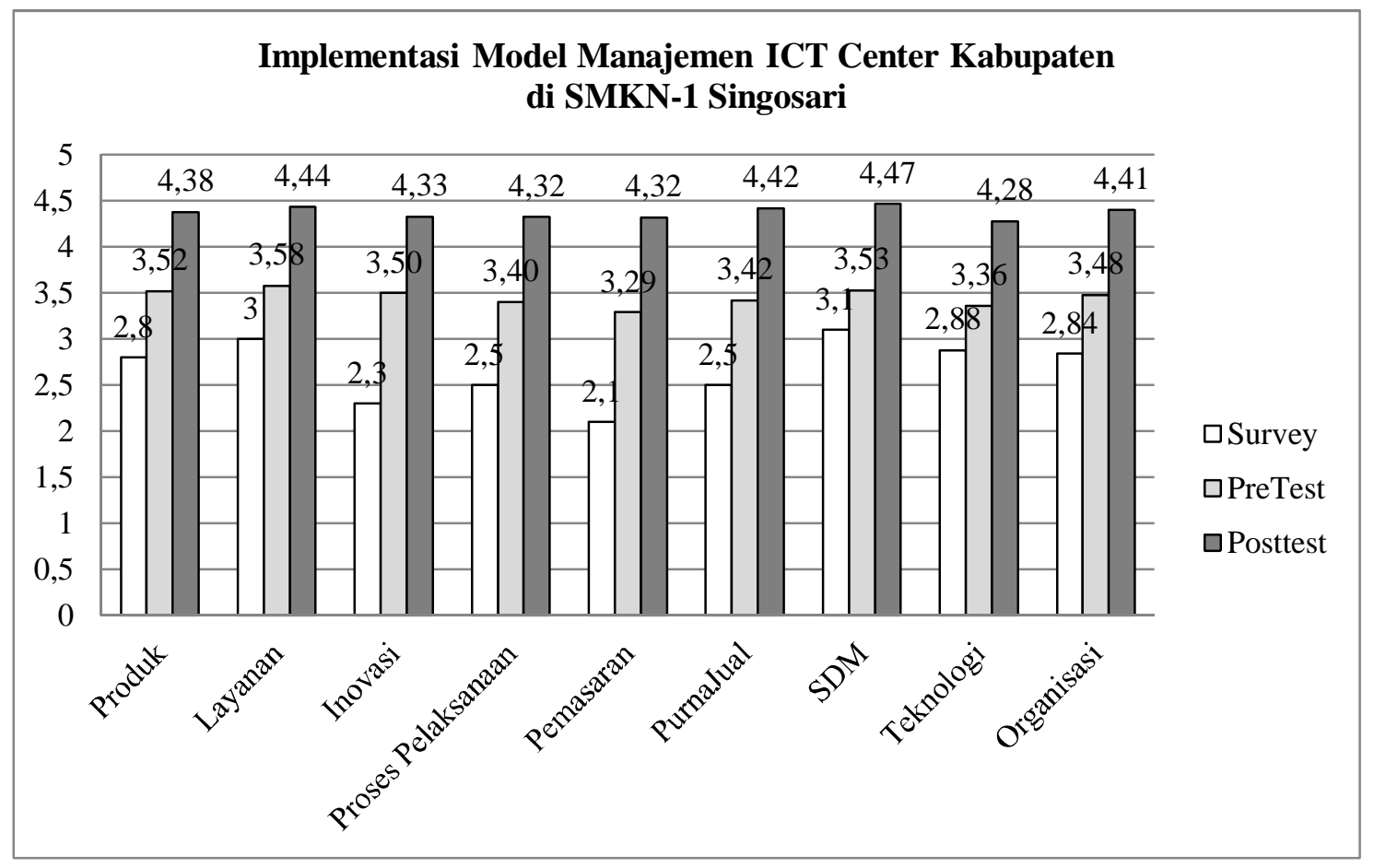

Gambar 4. Rerata penilaian aspek manajemen pada survey, pretest dan posttest 
Hasil komparasi dari kepuasan stakeholders melalui hasil survey, sebelum dan sesudah ICT center mendapat perlakuan, diperoleh perbedaan yang baik yaitu peningkatan layanan ICT center menurut persepsi stakeholders sekolah sebagai pemanfaat teknologi informasi komunikasi. Hasil ini cukup sesuai dengan konsep dampak kepuasan stakeholders sebagaimana yang diungkapkan Gigler (2005) bahwa informasi bukan hanya sumber pengetahuan tetapi juga sumber daya spesial yang bisa memajukan pendidikan, kebebasan ekonomi, sosial, politik, dan budaya. Bisa dikatakan bahwa akses dan pemanfaatan informasi dan komunikasi adalah kondisi dasar untuk pembangunan karena memberikan dampak pada setiap dimensi kehidupan.

Era teknologi informasi komunikasi sekarang, menuntut masyarakat modern untuk selalu berfikir effisiensi dan efektivitas dalam mengoptimalkan waktu mereka, maka kebutuhan informasi yang instan dan dapat dipertanggung jawabkan bagi masyarakat adalah situs atau web site. Berikut beberapa manfaat website sekolah untuk stakeholders internal sekolah antara lain adalah (a) sekolah mempunyai data data profil siswa yang akurat; (b) membantu siswa dalam berkreasi; (c) menampilkan profil sekolah yang uptodate; (d) terjalinnya interaksi antar siswa guru dan siswa yang tidak terbatas dengan ruang dan waktu; (e) mengenalkan profil sekolah pada dunia luar; (f) menyediakan sarana belajar bagi siswa yang tidak terbatas dengan ruang dan waktu; (g) melihat informasi informasi terbaru dari sekolah; (h) mengakses materi materi pelajaran yang ada disekolah dan tak terbatas; (i) bagi siswa dapat menjadikan tempat untuk menyalurkan kreasi di web sekolah.

Adapun manfaat Web Sekolah bagi stakeholders eksternal sekolah, antara lain adalah (a) masyarakat bisa mengakses data data tentang sekolah tanpa harus datang ke sekolah; (b) melihat perkembangan kemajuan sekolah (SDM, infrastruktur, prestasi dan sebagainya); (c) mengamati kegiatan kegiatan sekolah; (d) dapat dijadikan referensi dan rujukan untuk memilih sekolah yang benar benar berkualitas.

Berdasar ilustrasi manfaat bagi internal dan eksternal sekolah tersebut, maka peneliti mencoba mengungkapkan bagaimana aktivitas akses informasi pendidikan dari stakeholders sekolah terhadap kinerja manajemen ICT center melalui web server ICT center Kota sebagai komparasi dengan tanggapan responden dari stakeholders sekolah. Statistik aktivitas stakeholders SMKN-4 Malang sebagaimana pada Gambar 5, merupakan rekaman aktivitas web server selama 4 bulan yang merupakan waktu sebelum organisasi ICT sekolah mendapat perlakuan sampai pada saat mendapat perlakuan sampai batas waktu yang ditentukan. Banyak data dari statistic web portal sekolah, namun diambil beberapa data yang paling menggambarkan aktivitas pengunjung yang berkepentingan akan informasi elektronik sekolah yang dibangun, dioperasikan dan dirawat oleh Divisi ICT center. Data tersebut adalah jumlah dari hit, files, pages dan visits.

Analisis data web statistic yang diambil dalam bagian ini, menjelaskan bahwa pada variabel Hit, mengilustrasikan banyaknya file 
yang diminta pengunjung dari server website (situs sekolah). Gambar 5, diketahui bulan Juni sebanyak 146.343 files, bulan Juli sebesar 295.023 files, bulan Agustus 2011 adalah 119.935 files dan September melonjak kembali sebesar 220.999 files. Grafik yang kecenderungan mirip tersebut, juga nampak pada variable pages dan visits cenderung Juli mengalami kenaikan tertinggi kemudian turun pada Agustus dan kecederungan naik kembali pada bulan September 2011.

Kondisi tersebut tidak lepas dari kondisi saat bulan Agustus dan September banyak masa libur puasa dan lebaran. Kondisi yang real nampak pada bulan Juni dan Juli 2011, karena pada bulan tersebut aktivitas kegiatan PMB di sekolah pada kondisi normal dan wajar. Kondisi yang sedikit berbeda pada variable files yang merupakan gambaran banyak, kapasitas dan jenis data yang dibaca dan diambil oleh pengunjung situs sekolah menunjukkan grafik yang relative sedikit berbeda dengan ketiga variable sebelum, namun hal tersebut masih kecenderungan masih dalam batas normal karena perbedaannya tidak menyolok. Gambaran diatas menandakan adanya kemiripan dengan kondisi tanggapan instrument kinerja manajemen yang direspon oleh stakeholders sekolah sebelumnya. Grafik pada Gambar 5. memperlihatkan adanya pengaruh pengembangan model manajemen ICT center yang diimplementasikan.

Komparasi efektifan dari manajemen ICT center kabupaten ini dilakukan dengan statistik aktivitas stakeholders SMKN-1 Singosari lewat WEB yang dikelola oleh ICT center Kabupaten sebagaimana pada Gambar 6, merupakan rekaman aktivitas web server selama 4 bulan yang diambil saat sebelum organisasi ICT sekolah tersebut mendapat perlakuan sampai pada saat mendapat perlakuan sampai batas waktu yang ditentukan. Banyak data dari statistic web portal sekolah merupakan ilustrasi dari kompleknya aktivitas pengunjung yang dapat direkam. Namun, dalam hal ini diambil beberapa data yang paling menggambarkan aktivitas pengunjung yang berkepentingan akan informasi elektronik sekolah yang dibangun, dioperasikan dan dirawat oleh Divisi ICT center. Data tersebut adalah jumlah dari hit, files, pages dan visits.

Analisis data web statistic yang diambil dalam bagian ini, menjelaskan bahwa pada variabel Hit, mengilustrasikan banyaknya file yang diminta pengunjung dari server website (situs sekolah). Dari Gambar 6, diketahui sejak bulan Agustus hingga bulan November 2011 menunjukkan kecenderungan naik dengan ritme yang mirip sebagaimana pada Lampiran 20, secara berturut-turut banyaknya file yang diminta stakeholders sekolah adalah Agustus sebanyak 146.343, bulan September sebesar 295.023, bulan Oktober adalah 119.935 dan November semakin melonjak sebesar 220.999. Grafik yang kecenderungan mirip juga nampak pada variable pages, files dan visits cenderung Agustus ke September mengalami penurunan aktivitas pengunjung kemudian naik pada Oktober dan kecederungan naik kembali pada bulan November. Kondisi tersebut tidak lepas dari kondisi saat bulan Agustus dan September banyak masa libur puasa dan lebaran. Kondisi 
yang ideal nampak pada bulan Oktober dan November 2011, karena pada bulan tersebut aktivitas kegiatan PMB di sekolah pada kondisi normal dan wajar.

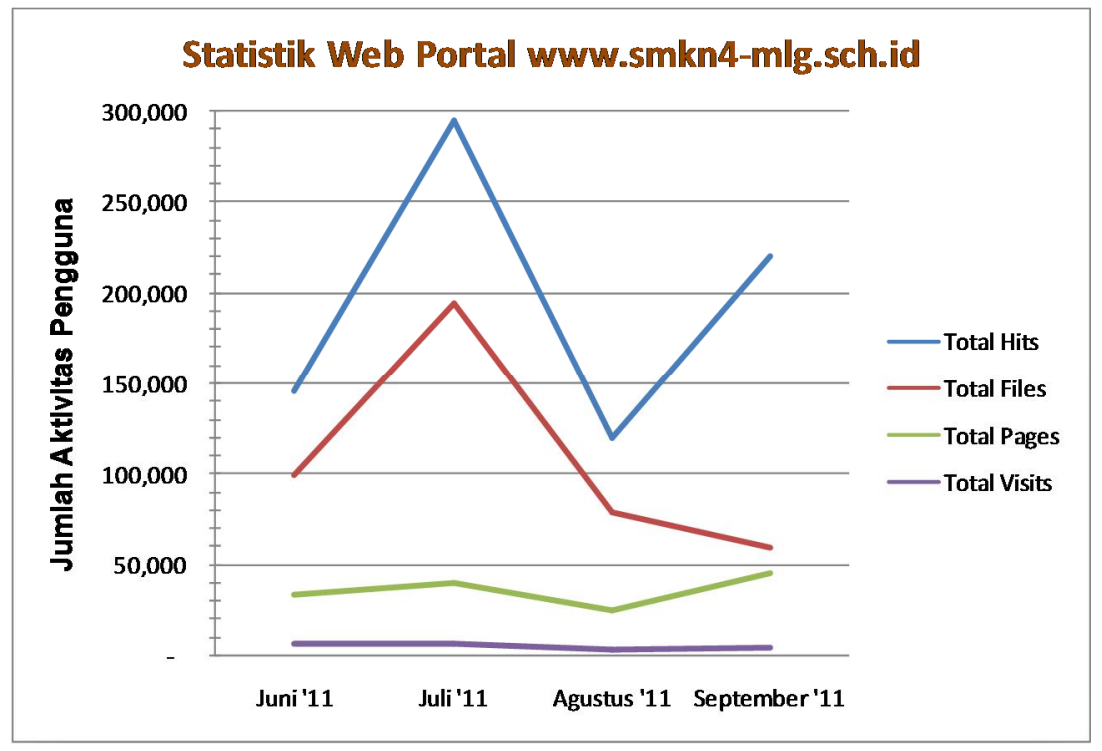

Gambar 5. Statistik pengunjung web portal SMKN-4 Malang

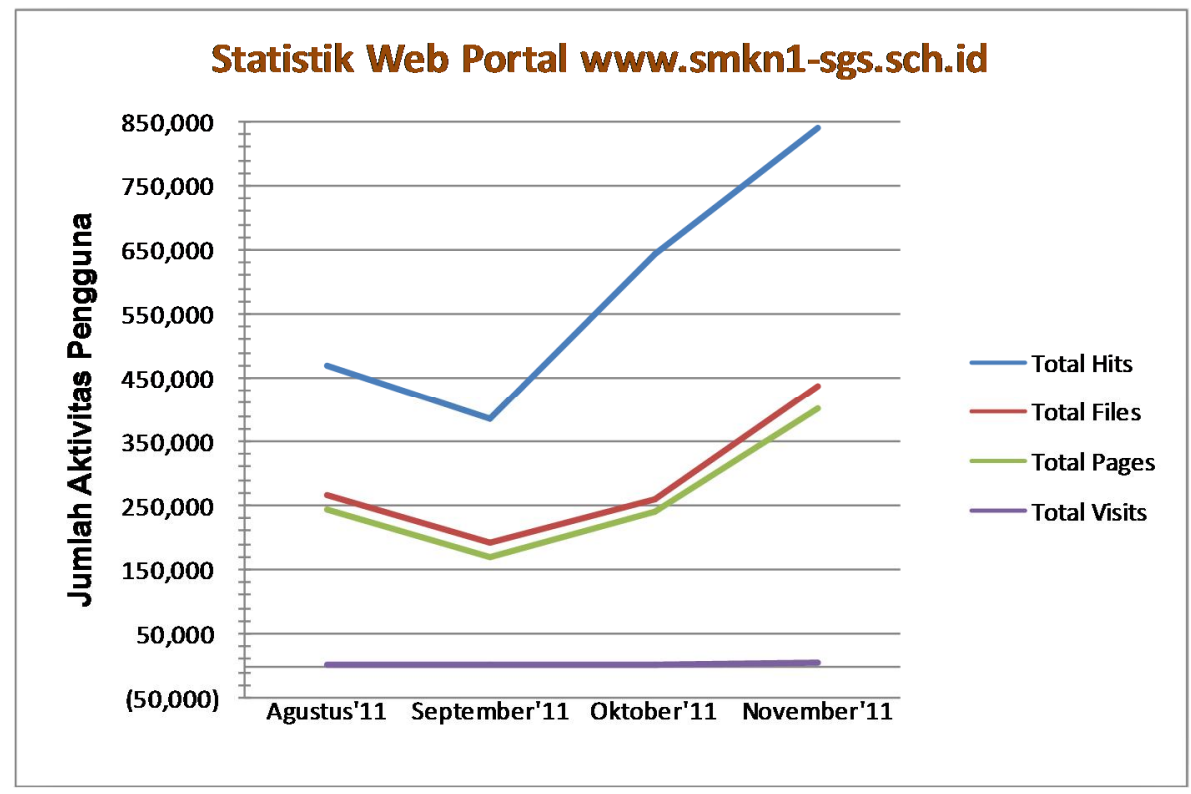

Gambar 6. Statistik Pengunjung web Portal ICT center Kabupaten

Kondisi yang sedikit berbeda pada variable files yang merupakan gambaran banyak, kapasitas dan jenis data yang dibaca dan diambil oleh pengunjung situs sekolah menunjukkan grafik yang relative sedikit berbeda dengan ketiga variable sebelum, namun hal tersebut masih kecenderungan masih dalam batas normal karena perbedaannya tidak menyolok. Gambaran diatas menandakan adanya kemiripan dengan kondisi tanggapan yang direspon oleh stakeholders sekolah sebelumnya. 
Grafik pada Gambar 6, memperlihatkan adanya pengaruh positif pengembangan model manajemen ICT center yang diimplementasikan. Hal ini salah satu indikator kepedulian stakeholders sekolah dengan teknologi informasi komunikasi sekolah, dengan demikian kontribusi mutu sekolah diharapkan dapat meningkat secara berkelanjutan sampai pada kondisi ideal yang sesuai dengan yang diharapkan pemangku kepentingan pendidikan pada sekolah menengah kejuruan.

\section{KESIMPULAN}

Berdasarkan hasil temuan dari penelitian dan pengembangan model manajemen ICT center yang diujicobakan di ICT center Kota dan Kabupaten Malang dapat diperoleh simpulan dan saran sebagaimana berikut:

1. Berdasarkan hasil survey ICT center di 12 daerah Jawa Timur diketahui bahwa secara rata-rata persentase tanggapan ICT center di daerah hasil survey diketahui sebesar $54,63 \%$. Hasil tersebut menjelaskan bahwa manajemen ICT center berada pada tingkatan kelayakan yang cukup. Secara keseluruhan hasil survey dengan bantuan hibah sarana dan prasarana hibah yang pernah diperoleh belum berkontribusi terhadap peningkatan mutu sekolah. Dari 12 lokasi tersebut hanya SMK Canda Bhirawa Pare-Kediri yang pengelolaan ICT centernya cukup baik, hal tersebut karena komitmen kepala sekolah yang cukup tinggi, sehingga atmosfir akademik dan kebutuhan ICT bagi sekolah terus terbina dan terfasilitasi dengan baik.
2. Ujicoba produk terhadap tenaga ahli dengan karakteristik subyek uji coba ahli dilakukan oleh ahli Manajemen Sumber Daya, ahli Manajemen Infrastruktur ICT, ahli Administrasi Pendidikan dan Praktisi ahli ICT untuk Pendidikan. Hasil rerata peraspek dan per tenaga ahli diperoleh hasil dengan skala persentase sebesar diatas $81 \%$. Hal tersebut menjelaskan bahwa secara keseluruhan tanggapan terhadap produk penelitian ini sangat layak untuk diimplementasikan.

3. Berdasarkan 9 aspek yang digunakan dalam uji coba produk skala terbatas pada ICT center Kota diperoleh delta rating penilaian pre-posttest stakeholders yaitu sebesar 0,459 . Sedangkan pada uji coba pada skala lebih luas di ICT center Kabupaten diperoleh delta rating penilaian pre-posttest stakeholders yaitu sebesar 0,92 . Hasil ini menjelaskan bahwa model ini memenuhi kriteria efektif dalam pengelolaan ICT center, sehingga diharapkan dapat mempunyai dampak terhadap mutu SMK secara keseluruhan.

4. Aspek SDM mempunyai delta rating penilaian stakeholders tertinggi dari 8 aspek manajemen lainnya yaitu sebesar 0,48 . Hal tersebut sangat berperan bagi keberlanjutan pengelolaan teknologi informasi komunikasi sekolah, aspek ICT tidak lebih hanya sebuah alat bagi kehidupan manusia dalam menjalankan tugas atau pekerjaannya. Hal ini relevan dengan McDonagh, et. all, (2000) bahwa aspek ICT hanya memberikan sumbangan 
kurang lebih $10 \%$ terhadap kesuksesan pengelolaan ICT center. Sementara $\pm 90 \%$ keberhasilan bersumber dari faktor manusia dan sosial organisasi.

\section{UCAPAN TERIMA KASIH}

Penyelesaian penelitian dan penulisan artikel ini tak lepas dari bantuan dan dukungan dari berbagai pihak. Dalam kesempatan ini, penulis menyampaikan ucapan terima kasih yang tak terhingga kepada: (1) Kemendiknas yang telah memberikan kesempatan penulis untuk mengembangkan penelitian melalui hibah doktor tahun 2011; (2) Direktur PPs Universitas Negeri Yogyakarta, para partisipasi penelitian ini yang penuh akraban memberikan dorongan moral, serta segenap staf administrasi, atas segala kebijaksanaan, perhatian, bantuan, yang diberikan sehingga penulisan ini dapat selesai.

\section{DAFTAR PUSTAKA}

Azwar, S. 2003. Sikap Manusia "Teori dan Pengukurannya". Yogyakarta : Pustaka Pelajar.

Borg, W.R. \& Gall, M. D. 1989. Educational Research: An Introductional (The fifth Edition), New York: Longman, Inc.
DeLone, W.H. and McLean, E.R. 1992. Information system success: The Quest for The dependent Variable. Information System Research. 60-95

Depdiknas. 2003. Undang-Undang RI Nomor 20, Tahun 2003, Tentang Sistem Pendidikan Nasional.

Gatot, H.P., dkk. 2008. e-Indonesia Initiative 2008 (eII2008). Jakarta: Konferensi dan Temu Nasional Teknologi Informasi dan Komunikasi untuk Indonesia.

Gigler, B.S. 2005. Enacting and Interpreting Technology from Usage to Well-being: Experiences of Indigenous People with ICT. Di dalam Empower Marginal Communities with Information Networking. Diedit oleh Hakikur Rahman. Hershey, Pen.: Idea Group. 124-164.

Laudon, Kenneth C. and Jane P. L. 2002. Management Information System: Managing the Digital Firm, $7^{\text {th }}$. New Jersey : Prentice-Hall.

McDonagh, P., et. all. (2000). Euroclicking and the Irish SME: Prepared for e-commerce and the single currency? Irish Marketing Review, 13(1), 21-33.

Nonaka I. dan Takeuchi, H. 1995. The Knowledge- Creating Company: How Japanese Companies Create the Dynamics of Innovation. Oxford: Oxford University Press.

Schreurs, J. 2007. ICT use in school: vision and performance measures. Villach-Austria: Procceding Conference ICL2007. 